\title{
O viés da cobertura política da imprensa nas eleições presidenciais brasileiras de 2002, 2006 e $2010^{2}$
}

\section{Political press coverage bias during the Brazilian presidential elections of 2002, 2006 and 2010}

Have you seen what they said on the news today?

Have you heard what they said about us all?

When the Wild Wind Blows - Iron Maiden

Estudos sobre o viés da cobertura política da imprensa são importantes, porque o que ele diz, como diz, com que ênfase ou até mesmo oculta pode influenciar o comportamento e as atitudes políticas dos eleitores (GROELING e KERNELL, 1998; KAHN e KENNEY, 2002; DRUCKMAN e PARKIN, 2005; DELLAVIGNA e KAPLAN, 2007; ENTMAN, 2007; GERBER, KARLAN e BERGAN, 2009; PUGLISI, 2011). Por conta disso existem, na literatura

\footnotetext{
1 É professor de Ciência Política da Universidade Federal de Goiás, Goiânia, GO, Brasil. E-mail: <psmundim@ufg.br>.

2 A ideia de escrever este artigo surgiu em 2009, durante o meu doutorado no antigo IUPERJ (atual IESPUERJ), por sugestão do meu orientador, Prof. Marcus Faria Figueiredo. Seu incentivo foi fundamental para que o texto começasse a tomar forma. Por conta disso, nada mais justo do que dedicá-lo à sua memória. Versões anteriores do artigo foram apresentadas em reuniões do Grupo de Pesquisa em Mídia e Esfera Pública (EME) da UFMG, na 7a Jornada Comunicação e Democracia, na UFBA, no $5^{\circ}$ Congresso da Compolítica, na UFPR, na 4a Conferência da International Communication Association (ICA) para a América Latina, na UnB, e no $9^{\circ}$ Encontro da Associação Brasileira de Ciência Política (ABCP), em Brasília. Agradeço aos participantes desses eventos suas críticas e sugestões, especialmente a Wilson Gomes e Fernando Lattman-Weltman. Também pude discutir o conteúdo do texto com Francisco (Franck) Mata Machado Tavares e João Carlos Amoroso Botelho, na UFG, a quem sou grato pelos valorosos comentários. Por fim, agradeço às observações dos pareceristas anônimos da RBCP.
} 
brasileira, vários trabalhos sobre a inclinação dos jornais, revistas e telejornais a favor (ou contra) determinado partido ou candidato nas eleições presidenciais (ALDÉ, FIGUEIREDO e MENDES, 2007; ALDÉ, 2003; KUCINSKI, 1998, 2007; LATTMAN-WELTMAN, CARNEIRO e RAMOS, 1994; LATTMAN-WELTMAN, 2003; MATOS, 2008; MIGUEL, 1999, 2004; PORTO, 2008).

Nesses trabalhos, as explicações predominantes para o viés da cobertura política da imprensa encontram-se no lado de quem "oferta" as informações políticas. Principalmente para as abordagens mais críticas, ele refletiria as preferências ideológicas das chamadas "elites midiáticas" - jornalistas, editores e proprietários. ${ }^{3}$ Contudo, autores que nos últimos anos vêm discutindo o viés da cobertura, especialmente economistas, defendem que ele também poderia ser explicado pelo lado da "demanda" (BERNHARDT, KRAAS e POLBORN, 2008; GENTZKOW e SHAPIRO, 2010; HAMILTON, 2004; MULLAINATHAN e SHLEIFER, 2005). Ou seja, seria causado pela competição entre empresas jornalísticas e pela distribuição das "crenças" dos consumidores de notícia.

O objetivo desse artigo é analisar o comportamento político da imprensa brasileira no cenário político-eleitoral, a partir de uma perspectiva que busca avaliar tanto o lado dos produtores de notícia quanto dos consumidores. ${ }^{4}$ Isso será feito a partir de uma análise comparativa de três grandes jornais brasileiros nas eleições presidenciais de 2002, 2006 e 2010: Folha de S. Paulo, O Estado de S. Paulo e O Globo. ${ }^{5}$ Buscarei responder a questões como: houve um viés sistemático nas disputas? Os jornais tiveram um tom mais negativo sobre um candidato do que em relação aos demais?

3 Não pretendo me envolver nas batalhas terminológicas sobre o conceito de ideologia. Nesse sentido, trabalharei com uma definição estrita e simples do termo: "uma imagem verbal da boa sociedade e dos principais meios para construir tal sociedade" (DOWNS, 1999[1957], p. 117). Para discussões pormenorizadas sobre o conceito, ver Gerring (1997).

4 Por exemplo, ao analisar a mudança de comportamento do Jornal Nacional nas coberturas das eleições de 2002 e 1998, Miguel (2004, p. 306) apresenta a possibilidade de múltiplas combinações causais - "natureza jornalística, empresarial ou política" - que seriam necessárias para explicá-la. Contudo, como ele mesmo escreveu, "é possível apenas especular" sobre essas razões.

5 Por simplicidade, a partir de agora irei me referir aos jornais como Folha, Estadão e O Globo. 
$\mathrm{O}$ viés da cobertura variou entre as eleições e entre os veículos? (D’ALESSIO e ALLEN, 2000)

$\mathrm{O}$ artigo está estruturado da seguinte forma. Na primeira e segunda partes, apresento as discussões teóricas sobre o viés da cobertura política da imprensa e suas possíveis causas a partir de uma perspectiva que busca avaliar tanto o lado dos produtores de notícias quanto dos consumidores. Embora sejam objeto de análise de vários campos do conhecimento, neste artigo enfatizarei as discussões feitas por cientistas políticos, comunicólogos e economistas. Enquanto os dois primeiros geralmente apresentam abordagens críticas, típicas dos trabalhos de economia política da comunicação, os últimos enfatizam os efeitos do comportamento maximizante dos indivíduos e/ou grandes conglomerados comerciais sobre o conteúdo dos jornais.

$\mathrm{Na}$ terceira e quarta partes, apresento as análises empíricas. Os dados utilizados são provenientes da Planilha de Monitoramento da Cobertura da Mídia Impressa do Doxa-IESP, que avaliou o conteúdo da cobertura eleitoral dos três jornais citados acima. ${ }^{6}$ Metodologicamente, assumo como válidas as posições críticas. Assim, considero o argumento de que a imprensa brasileira atua como um bloco de ação política, ideologicamente motivado, como uma hipótese nula a ser aceita ou refutada por análises estatísticas.

Essas análises serão de dois tipos. Primeiramente, examino o que se pode chamar de dimensão quantitativa do viés da cobertura política da imprensa, ou "viés de cobertura", nas palavras de D’Alessio e Allen (2000). Seguindo a lógica das abordagens de Porto (2008) e Aldé, Mendes e Figueiredo (2007), analiso se a visibilidade dos candidatos estaria em desacordo com critérios objetivos de noticiabilidade: a importância política de um concorrente, principalmente postulantes à reeleição ou apoiados pela situação,

6 Em 2002 e 2006, o Doxa-IESP incluiu na análise o Jornal do Brasil. Em 2010, o periódico ficou de fora por ter parado de circular. Por questões de homogeneidade na comparação nas três eleições, decidi excluí-lo da análise. Agradeço a Alessandra Aldé a gentileza em disponibilizar os bancos de dados das análises da cobertura da mídia impressa realizada pelo Doxa-IESP. Esse agradecimento é extensivo aos bolsistas que participaram da análise de conteúdo e aos financiadores do trabalho: Faperj, Finep, Capes e CNPq. 
e a posição na disputa eleitoral. Qualquer desvio dessa conduta indicaria um desequilíbrio na cobertura e, possivelmente, a existência de viés.

Contudo, a dimensão quantitativa da cobertura política da imprensa tem limitações. O equilíbrio na visibilidade não se traduz, necessariamente, em um equilíbrio na maneira positiva ou negativa que os candidatos são apresentados. Por isso, também analiso a dimensão qualitativa do viés da cobertura, ou "viés de declaração", que ocorre quando, para um determinado evento midiático, há uma "preponderância de declarações favoráveis para um lado" da história (D'ALESSIO e ALLEN, 2000, p. 137). Isso foi feito a partir do índice de viés da cobertura inspirado no trabalho de Bernhardt, Krasa e Polborn (2006, 2008), que leva em conta as valências positivas e negativas do conteúdo publicado sobre os candidatos. ${ }^{7}$

Esse índice de viés de cobertura oferece uma vantagem em relação às análises que levam em conta apenas a cobertura política da imprensa sobre um candidato em particular. Ele é construído a partir da soma de notícias positivas e negativas publicadas, respectivamente, sobre um candidato e seu principal concorrente. A partir dessa ideia, criei um índice de viés de cobertura anti-PT que considera o número de matérias negativas publicadas sobre o candidato petista e o número de matérias positivas publicadas sobre os candidatos do PSDB em diferentes veículos, em um mesmo período de tempo, em cada uma das eleições. Isso me permitiu analisar o viés da cobertura política da imprensa de um ponto de vista bastante diferente de outros estudos publicados no Brasil até agora (CAMARGOS e OLIVEIRA, 2000; ALDÉ, 2003; CERVI, 2003; ALDÉ, MENDES e FIGUEIREDO, 2007; ARMONY, 2009; MIGUEL et al, 2013; FERES JÚNIOR e SASSARA, 2016).

7 Em algumas das apresentações desse trabalho surgiram questionamentos sobre a validade das valências como um indicador do viés da cobertura. Os procedimentos metodológicos empregados pelo Doxa-IESP estão descritos em Aldé (2003). Como escrevi em outro texto (MUNDIM, 2012, p. 129), é verdade que pesquisadores e analistas divirjam sobre qual é a melhor maneira de medilas. Mas desconheço algum estudo que tenha analisado, com testes empíricos, como modificar a métrica que busca medir essa dimensão qualitativa da cobertura da imprensa. Por essa razão, acredito que trabalhar com os tradicionais conceitos de negativo, neutro e positivo ainda seja um critério plenamente aceitável do ponto de vista científico. 
Embora os dados mostrem a ocorrência de viés na cobertura política da imprensa, especialmente no chamado conteúdo opinativo dos jornais (colunas, editoriais e artigos), na eleição presidencial de 2006 não foi encontrado um padrão claro e sistemático de preferência por determinado candidato nas páginas da Folha, Estadão e $O$ Globo. Independentemente do tipo de análise estatística aplicada, os resultados dos testes rejeitaram a hipótese de um comportamento homogêneo dos três jornais analisados. Isso torna difícil aceitar a ideia da existência de uma "grande imprensa", agindo em uníssono e voltado, insistentemente, contra os candidatos petistas, ao menos no que diz respeito aos três períodos eleitorais analisados neste artigo e tendo em vista a base de dados sobre a cobertura da imprensa do Doxa-IESP.

\section{Discussões teóricas sobre o viés midiático ${ }^{8}$}

Segundo Baron (2006, p. 4), o viés midiático é resultado da "falta de equilíbrio" que ocorre quando um lado da história recebe mais atenção do que outro. Já Stevenson e Greene (1980, p. 116) o definem como "um tratamento diferenciado de um candidato, partido ou lado da questão durante um longo período de tempo (...) uma falha por não conseguir tratar igualmente todas as vozes no mercado [de ideias]". Mullainathan e Shleifer (2005, p. 1040) assumem que "os jornais inclinam [sua cobertura] ao omitir seletivamente pedaços de notícias, i.e., não reportando toda a verdade" (grifo meu). Por sua vez, Cook (2011, p. 206-207) argumenta que a "seletividade leva ao viés quando, dia sim, dia não, certos tipos de atores, partidos políticos e questões receberem maior cobertura e forem apresentados mais favoravelmente que outros".

Neste artigo assumo posição semelhante à desses autores, assim como o fizeram Bernhardt, Krasa e Polborn (2008, p. 1093), para quem "o viés midiático se manifesta como supressão da informação. Ou seja, a mídia pode seletivamente omitir informações relevantes

8 Os autores apresentados neste item utilizam o termo viés midiático (media bias) ou inclinação (media slant) para se referirem ao viés de cobertura política encontrada na imprensa. Mantive essa classificação no texto ao discuti-los. 
(...), mas não pode simplesmente 'fabricá-las"'. Como Groseclose e Milyo (2005, p. 1.205), entendo que o viés não ocorre por desonestidade, mas pela preferência na escolha de "fatos ou histórias em que apenas um lado do espectro político é mencionado".

Independente das áreas de conhecimento de origem, a maioria das interpretações sobre o viés midiático busca explicá-lo, principalmente, de duas maneiras: pelos lados da "oferta" e da "demanda", por assim dizer. O primeiro caso caracteriza-se no que Hofstetter (1976) e Cook (2011) chamaram de "viés político" e enfatiza as razões pelas quais jornalistas, editores e proprietários - as chamadas "elites midiáticas" - decidem refletir seus valores liberais ou conservadores, de esquerda ou de direita, em seus veículos (D'ALESSIO e ALLEN, 2000; BOVITZ, DRUCKMAN e LUPIA, 2002). O segundo caso enfatiza como as características dos consumidores, seus valores e suas preferências políticas geram incentivos às empresas jornalísticas para "enviesar suas histórias oferecidas a uma clientela particular". (BARON, 2006, p. 2)

No lado da oferta, boa parte das explicações para o viés da cobertura política da imprensa se encontra em dois tipos de abordagem, o que não significa que mantenham um diálogo. Existem trabalhos que tentam explicá-lo a partir dos incentivos econômicos das elites midiáticas (BARON, 2006; BOVITZ, DRUCKMAN, \& LUPIA, 2002). ${ }^{9}$ E existem trabalhos que tentam explicá-lo a partir das posições ideológicas e políticas dessas mesmas elites (AMARAL, 2006; KUCINSKI, 2007). ${ }^{10}$ Entendo que, no Brasil, as interpretações "conspiratórias dos barões da imprensa", como interpretou Azevedo (2009, 2010), ou dos “críticos radicais", nas palavras de Matos (2008), poderiam ser enquadradas nessa segunda dimensão teórica.

9 Em seu artigo Baron (2006, p. 2), por exemplo, "considera uma explicação do lado da demanda de que a existência e a persistência do viés midiático se baseiam na informação incompleta e nas perspectivas de carreira dos jornalistas. Enviesar as histórias pode aumentar a probabilidade de que a história de um jornalista seja publicada ou pode promover a visão de mundo deste jornalista".

10 Os estudos sobre jornalismo e produção de notícia apontam que o viés do lado da oferta também pode ocorrer em função das próprias rotinas jornalísticas (GANS, 1980; COOK, 2011). De todo modo, a ênfase da literatura sobre viés midiático utilizada neste artigo enquadra as discussões em uma perspectiva mais política e menos técnica. Mantive-me fiel a esse recorte no texto. 
Por sua vez, o lado da demanda tem uma forte influência do modelo de competição espacial e diferenciação de produtos de Harold Hotelling, que se tornou famoso na Ciência Política na discussão de Downs (1999 [1957]) sobre a dinâmica das ideologias partidárias. Essa perspectiva é defendida por autores em trabalhos tanto de caráter mais teórico quanto em trabalhos de caráter mais empírico.

No primeiro caso, Mullainathan e Shleifer (2005), Xiang e Sarvary (2007), Bernhardt, Krasa e Polborn $(2006,2008)$ e Stone (2011) mostraram como a distribuição ideológica da audiência gera incentivos econômicos para que as empresas jornalísticas segmentem o mercado e façam coberturas enviesadas. Isso ocorreria, principalmente, onde os consumidores selecionam ideologicamente as informações que consomem - o que parece ser o caso dos EUA (IYENGAR \& HAHN, 2009; PRIOR, 2013).

No segundo, Hamilton (2007, p. 11) defendeu que o viés midiático é "melhor explicado como surgindo das escolhas econômicas do que das fobias e falhas humanas". Em um dos raros trabalhos que buscou testar qual interpretação teria maior poder explicativo, Gentzkow e Shapiro (2010) concluíram que as empresas jornalísticas americanas respondem mais às preferências dos consumidores do que à identidade política de seus proprietários.

Desconheço algum trabalho que tenha se inspirado no referencial teórico do lado "da demanda" para analisar o viés da cobertura política da imprensa no Brasil. ${ }^{11}$ Mas se "a nossa grande imprensa atual está estruturada de forma empresarial num mercado de informação bastante competitivo e sua fonte de financiamento depende basicamente da circulação e dos anunciantes", como sugere Azevedo (2009, p. 48), é possível analisar em que medida nossos jornais são movidos pelos valores de seus proprietários, editores e jornalistas e/ou de seus leitores.

11 Mais uma vez, é importante enfatizar que essa afirmação se refere a trabalhos sobre o viés midiático. 


\section{A economia e a ideologia das notícias políticas}

Neste artigo, adotarei duas grandes linhas de discussão sobre o que define o conteúdo da cobertura política da imprensa. Do lado da oferta, as abordagens de ideologia e conflito de classes, especialmente análises mais críticas como as de Kucinski (1998, 2007), Nassif (2007) e Rovai (2007) ${ }^{12}$ e, do lado da demanda, as abordagens econômicas como as de Hamilton (2004, 2007).

É importante deixar claro que nem as perspectivas do lado da demanda nem as do lado da oferta apresentam posicionamentos puros, embora enfatizem alguns deles mais do que outros. Além disso, ao trabalhar com conceitos como "ideologia" e "conflito de classes", utilizo uma generalização que nem sempre corresponde à heterogeneidade de interpretações e usos desses termos, principalmente na literatura especializada. ${ }^{13}$ Contudo, por razões de simplicidade, decidi mantê-los assim no texto. E, por razões de clareza, decidi apresentar separadamente as duas grandes linhas de discussão sobre o que define o conteúdo da cobertura política da imprensa.

\section{A economia das notícias}

Segundo Hamilton (2004, p. 4), a notícia é uma mercadoria moldada pelas forças da lei da oferta e da procura. Com essa visão, o autor argumenta que os modelos utilizados por economistas para estudar o funcionamento do mercado, tendo em vista o "desejo dos consumidores", podem ser adaptados para predizer e analisar o conteúdo da cobertura das notícias, ou a "economia das notícias".

A partir dessas duas premissas, Hamilton (2004) desenvolveu um "modelo espacial de localização dos produtos" que leva em conta o desejo de consumidores $X$ (quem se interessa pela informação, e qual é o seu perfil), de anunciantes $P$ (o quanto estão dispostos a pagar

12 Embora nem todas as análises críticas e radicais sejam, stricto sensu, estudos empíricos ou teóricos, mas textos ensaísticos, penso que a posição de autores como Kucinski ilustra bem os argumentos levantados contra o comportamento político da imprensa brasileira. Agradeço a Wilson Gomes por me chamar atenção para este fato.

13 Agradeço a Fernando Lattman-Weltman por me chamar atenção para este fato. 
para alcançar os consumidores), além do número de concorrentes $N$ e os custos de produção $C$.

Consideremos o mercado de notícias para um determinado dia em particular. Seja $X_{e}$ o número de pessoas (em milhares) que optam por consumir notícias políticas à esquerda do espectro político, $X_{c}$ o número de pessoas (em milhares) que optam por consumi-las ao centro, e $X_{d}$ o número de pessoas (em milhares) que optam por consumi-las à direita. Os valores que os anunciantes estão dispostos a pagar a um veículo, em reais por mil consumidores, são denotados como $P_{e}, P_{c}$ e $P_{d}$. O número de veículos que optam por oferecer conteúdos políticos ideologicamente posicionados à esquerda, centro e direita são definidos por $N_{e}, N_{c}$ e $N_{d}$.

Assumindo-se, por simplicidade, que os consumidores usufruem apenas dos produtos de sua preferência ideológica, e que os custos de produção $C$ são fixos e iguais, um veículo que opte por oferecer informações políticas com um viés à esquerda pode ser definido como $P_{e}{ }^{\star}\left(X_{e} / N_{e}\right)-C$. Segundo Hamilton (2004, p. 267), em equilíbrio, os lucros dos veículos que oferecem cada tipo de produto serão iguais, como se pode ver na equação (1):

$$
\begin{aligned}
& P_{e}^{*}\left(X_{e} / N_{e}\right)-C=P_{c}^{*}\left(X_{c} / N_{c}\right)-C=P_{d}^{*}\left(X_{d} / N_{d}\right)-C \\
& \mathrm{e} \\
& N_{e}+N_{c}+N_{d}=N
\end{aligned}
$$

Contudo, na ausência de equilíbrio há incentivos para que se mude o conteúdo daquilo que se oferece em busca de um maior retorno financeiro. Assim, mudanças nas variáveis "exógenas" $X$, $P$ e $C$ afetam o comportamento do número de concorrentes $N$ que oferecem um determinado produto. Para ficar mais claro sobre como esse modelo é utilizado, vejamos dois exemplos simples e hipotéticos.

Em um mercado de consumidores com distribuição ideológica bimodal, a existência de apenas dois jornais concorrentes geraria incentivos econômicos para a segmentação de mercado, desde que os valores de $P$ e $C$ permanecessem fixos. $O$ mercado seria 
"dividido ao meio" e cada lado do espectro ideológico teria suas demandas por notícias atendidas. ${ }^{14}$ Haveria maior pluralidade de visões políticas e maior viés. Mas se a distribuição ideológica dos consumidores fosse semelhante à curva normal, em forma de sino, os mesmos veículos teriam incentivos econômicos para realizar coberturas mais neutras, caso quisessem atingir um maior número de leitores. Agora, haveria menos viés e menos pluralidade de visões políticas.

A distribuição ideológica do eleitorado brasileiro ajuda a ilustrar esse ponto. Os dados do Gráfico 1 trazem a distribuição ideológica dos eleitores do Rio de Janeiro, São Paulo e dos demais estados do País numa escala de 0 a 10 , onde 0 significa ser de esquerda e 10 significa ser de direita, controlada pelo grupo de escolaridade, um fator importante de exposição, recepção e retenção do conteúdo da cobertura política da imprensa (GRABE, KAMHAWI e YEGIYAN, 2009; AZEVEDO, 2011; MUNDIM 2012). ${ }^{15}$ Eles sugerem duas estratégias diferentes. O Globo tenderia a uma cobertura mais equilibrada, pois é praticamente o único jornal de notícias duras do estado e os cariocas com escolaridade superior se colocaram majoritariamente no centro na distribuição. Por outro lado, enquanto um dos jornais paulistas teria incentivos para uma cobertura política mais de centro-direita, o outro poderia focar o seu nicho de mercado nos leitores de centro-esquerda. Isso evitaria a concorrência entre apenas dois veículos por um grupo pouco numeroso de consumidores.

\footnotetext{
14 Paradoxalmente, poderíamos encontrar esse mesmo cenário em um monopólio, já que uma mesma empresa poderia oferecer dois tipos de produtos diferentes para agradar a todos os gostos. (MULLAINATHAN e SHLEIFER, 2005; STONE, 2007)

15 VerWood e Oliver (2012) para uma discussão das limitações dos indicadores de auto posicionamento ideológico. Para uma discussão sobre o perfil de consumidores de notícias, seja dos principais telejornais brasileiros, sejas dos jornais impressos, ver respectivamente Mundim (2015) e Nunomura (2015). Ambos trabalharam com os dados da Pesquisa Brasileira de Mídia 2014 e/ou 2015.
} 
Gráfico 1: Distribuição ideológica e valores médios do eleitorado brasileiro na escala de auto posicionamento

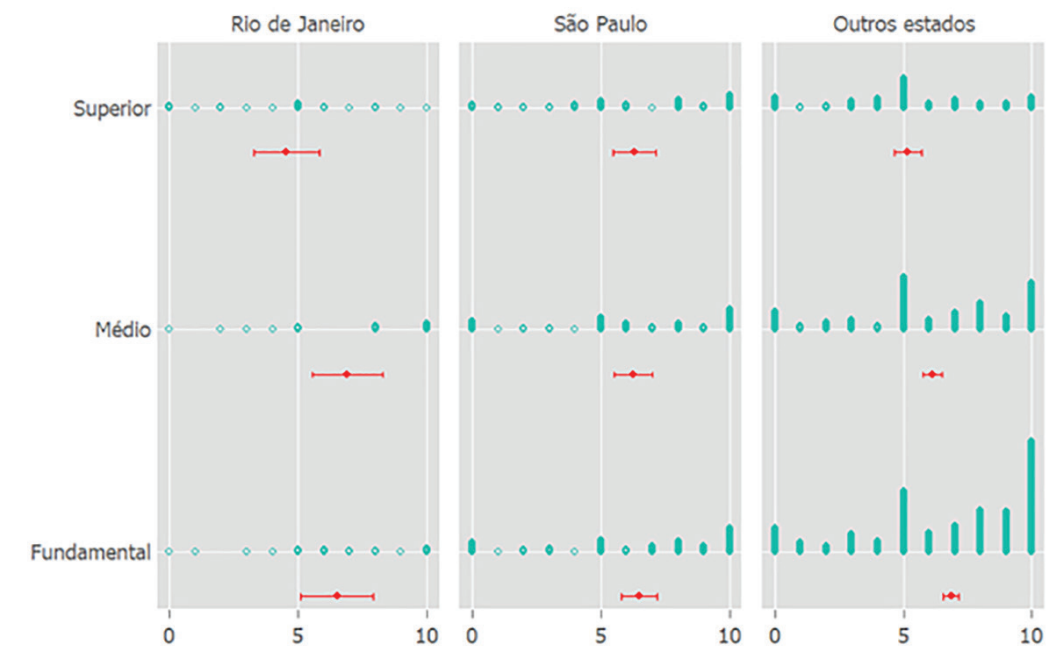

Fonte: ESEB 2010

É a partir desse modelo, portanto, que Hamilton discute o viés da cobertura política da imprensa. Para ele, "os proprietários dos jornais variam nos graus em que procuram obter lucros, o bem público, e fins partidários" (HAMILTON, 2004, p. 24). Alguns podem decidir posicionar suas marcas e formatar seus produtos de acordo com o público-alvo que desejam alcançar. Nesse sentido, deixar de veicular informações políticas, apresentá-las de forma neutra ou apoiar um partido é uma decisão estratégica de mercado. Um exemplo disso, segundo o autor, foi o surgimento da imprensa não partidária nos EUA no século XIX como um produto comercial: "ao juntar uma maior audiência um jornal poderia cobrar taxas mais altas dos anunciantes e tirar vantagem das economias de escala na produção de papel" (HAMILTON, 2004, p. 105). Além disso, Hamilton argumenta que:

geralmente as reclamações sobre o viés midiático são expressas em termos de conspiração, controle corporativo 
ou conflitos de classe. [Mas] As evidências apresentadas aqui sobre interesses da audiência e foco em grupos demográficos oferecem outras explicações (...). O viés político no conteúdo da mídia pode ser visto como semelhante a uma diferenciação de produtos. Os indivíduos têm visões de mundo e ideologias, que podemos pensá-las como suas preferências políticas. Empresas midiáticas podem escolher combinações de tópicos e abordagens a questões que reflitam essas visões de mundo. (HAMILTON, 2004, p. 105-106 grifos meus).

Mas Hamilton (2004, p. 24) reconhece que motivações adicionais a essas podem aparecer quando um meio de informação está sobre o controle de um indivíduo ou grupo familiar. Por um lado, eles podem abdicar de algum retorno financeiro em benefício do bem público, produzindo mais informações políticas do que de fato lhes é demandado, sem enviesar sua cobertura política. Por outro, podem decidir trocar o seu lucro por ideologia com o intuito de influenciar o resultado das eleições, declarando o apoio a um partido político. A questão é saber até onde eles iriam. Segundo o modelo teórico proposto por Bovizt, Druckman e Lupia (2002, p. 146), não muito longe: "na verdade, se as elites políticas querem usar as notícias para moldar o discurso político para seus próprios propósitos, múltiplas barreiras encontram-se no seu caminho”.

\section{A ideologia das notícias}

No Brasil, a visão de que donos dos veículos de informação sacrificam seu lucro por ideologia e pelo desejo de influenciar as eleições encontra respaldo junto a pesquisadores e analistas que assumem uma perspectiva crítica. Exemplo disso são as análises sobre a cobertura da imprensa nas eleições presidenciais de 2006.

Para Kucinski (2007, p. 133), em 2006, nossos principais jornalistas e veículos de informação comportaram-se de maneira homogênea, aderindo "espontaneamente ao antilulismo e seu correlato antipetismo". Na mesma perspectiva, Nassif (2007, p. 150) perguntou: "o que leva um setor, que deveria ser competitivo, 
a montar uma unanimidade em torno de uma estratégia [para a derrota de Lula] tão míope?". Já Rovai (2007, p. 118) assinalou:

interesses semelhantes, principalmente do ponto de vista político e econômico, (...) em certos momentos fazem alguns conglomerados empresariais de comunicação (...) se associarem e se tornarem um bloco de ação política.

Ao utilizarem palavras como "homogênea", "unanimidade" e "bloco de ação política" esses analistas estão defendendo que não existe diferença na cobertura política que os veículos de imprensa realizaram das eleições de 2006. Motivados por razões ideológicas dos proprietários, além da submissão, anuência ou passividade dos jornalistas e editores, alguns dos maiores grupos de informação do País teriam feito uma cobertura enviesada, anti-PT, independente dos desejos e características sociais e políticas de seus leitores e do que preconizaria a objetividade jornalística.

Mas essa crítica, contudo, não é nova. Autores brasileiros já levantaram restrições à cobertura política da imprensa, vista em grande medida como homogênea, tendenciosa e contrária às candidaturas de esquerda, como a petista, e a favor dos candidatos que defenderiam o status quo (KUCINSKI, 1998; LATTMANWELTMANN, RAMOS e CARNEIRO, 1994; LATTMANWELTMAN, 2003; LIMA, 2004; MIGUEL, 1999, 2004). ${ }^{16}$ Nessa crítica está implícita, principalmente nas análises mais radicais, a ideia de que a cobertura foi influenciada pelas preferências ideológicas de pequenos grupos de famílias conservadoras - os "barões da imprensa" - que controlam os grandes veículos de informação do país, conforme interpretou Azevedo $(2009,2010)$.

Nesse sentido, uma ideologia de classe moldaria a cobertura política da imprensa. Daí deduz-se que os jornais são um "sistema ideológico único, sem nuances, como se todos os meios de comunicação de massa no Brasil fossem comandados por um

16 Vale dizer que também existem críticas mais amenas (PORTO, 2007, 2012; MATOS, 2008). 
único editor, invisível, com a mudança apenas do público-alvo e do estilo dos diferentes veículos" (KUCINSKI, 2007, p. 138), e que os jornalistas são "profissionais passivos trabalhando em ambientes conservadores”. (KUCINSKI, 1998, p. 106)

\section{Construção de indicadores de viés da cobertura política}

A ideologia e a economia das notícias podem ser postas à prova por análises empíricas. A seguir, essas premissas teóricas serão descritas em forma de hipóteses, que podem ser refutadas ou não. Os dados utilizados são provenientes das Planilhas de Monitoramento da Mídia Impressa do Doxa-IESP, que possibilitarão uma análise comparativa da cobertura político-eleitoral dos jornais Folha, Estadão e Globo nas eleições presidenciais brasileiras de 2002, 2006 e 2010 .

\section{A distribuição de espaço como indicador do viés da cobertura da imprensa}

Ao menos em princípio, os jornais brasileiros adotam como critério de visibilidade a posição ocupada pelos candidatos na disputa eleitoral e a sua importância política, especialmente se postulantes à reeleição ou apoiados pela situação (ALDÉ, 2003; ALDÉ, MENDES e FIGUEIREDO, 2007). Nesse sentido, mesmo se o concorrente não estiver entre os favoritos, uma subida na preferência das intenções de voto dos eleitores levaria a um ganho de espaço nas páginas dos veículos.

Em relação à distribuição de espaço nos jornais, portanto, a hipótese nula a ser testada é a seguinte:

: devido aos interesses de classe, os jornais ignorarão as intenções de voto dos concorrentes e desrespeitarão o critério de equilíbrio de visibilidade entre os candidatos, dando mais espaço para seu candidato/partido preferido.

Para testar essa hipótese, compararei o espaço dado pelos jornais Folha, Estadão e $O$ Globo aos principais candidatos com as suas 
respectivas intenções de voto durante as eleições de 2002, 2006 e 2010. ${ }^{17}$ Esta abordagem é semelhante à do trabalho de Porto (2008), que confrontou o percentual de espaço obtido pelos concorrentes no Jornal Nacional com o total de votos que obtiveram nas eleições presidenciais de 1989, 1994, 2002 e 2006.

O espaço ocupado pelos concorrentes foi medido em termos percentuais. Para obter essa informação, utilizei o indicador de "visibilidade" presente na planilha do Doxa-IESP, que mensura o total de citações do nome do candidato por material analisado. Assim, para cada período entre as pesquisas de intenção de voto, dividi a soma do total de citações de cada um dos concorrentes pelo total de citações de todos eles.

\section{As valências como indicador do viés da cobertura da imprensa}

Críticos da cobertura política imprensa como Kucinski poderão argumentar, corretamente, que se deve analisar o viés da cobertura tendo em vista, também, a "qualidade" do que foi publicado sobre os candidatos, e não apenas a "quantidade" do espaço obtido. Afinal, mesmo com um equilíbrio na visibilidade entre dois concorrentes nas páginas dos jornais, é possível que a cobertura apresente viés caso um deles receba tratamento mais negativo do que o outro.

Existem vários estudos brasileiros que buscaram analisar esse tipo de viés da cobertura política da imprensa, a partir do uso das valências do conteúdo publicado sobre os candidatos. Alguns fazem análises agregadas a partir de tabelas cruzadas e testes de associação entre variáveis categóricas (CAMARGOS e OLIVEIRA, 2000; CERVI, 2003). Outros utilizam tabelas cruzadas e as séries históricas da evolução das coberturas negativas e positivas dos

17 As intenções de voto dos candidatos foram obtidas a partir dos dados de pesquisas dos institutos Datafolha, GPP, Ibope, Sensus e Vox Populi e IBPS, disponíveis no blog do repórter Fernando Rodrigues. Utilizei os dados da pergunta estimulada. Quando houve coincidência de datas entre as pesquisas, estimou-se uma média. Quando uma mesma pesquisa apresentou mais de um cenário, foi considerado o primeiro deles. Disponível em: < http://www.poder360.com.br/pesquisas-de-opiniao/>. Acesso em: 20 Out. 2013. 
candidatos. (ALDÉ, MENDES e FIGUEIREDO, 2007; ARMONY, 2009)

Penso, contudo, que análises agregadas não são adequadas para avaliar um processo dinâmico como é a cobertura da imprensa durante uma eleição, que respondem a uma série de acontecimentos e eventos de campanha que ocorrem no decorrer da disputa. Já a análise das séries históricas das coberturas proposta neste artigo, levando-se em conta a "valência" do conteúdo dos jornais, se diferencia das mencionadas acima por conta do uso de um índice de viés de cobertura inspirado no trabalho de Bernhardt, Krasa e Polborn (2006, 2008).

Teoricamente, esse índice de viés de cobertura se baseia na premissa de que "o viés midiático forma-se de maneira endógena como uma escolha ótima de empresas midiáticas em busca da maximização de seu lucro em resposta às preferências de (alguns) eleitores" (BERNHARDT, KRASA e POLBORN, 2006, p. 2). Ele ocorre pela "supressão da informação", já que não se pode "fabricar notícias" instantaneamente e a bel-prazer: "assumimos que a mídia pode seletivamente omitir informações relevantes que entram em conflito com as preferências e crenças de seus" leitores. (BERNHARDT, KRASA e POLBORN, 2006, p. 1-3)

Certamente, essa perspectiva tem limitações por assumir que o viés da cobertura é função apenas da distribuição das preferências ideológicas dos leitores/eleitores e que apenas o desejo dos consumidores seria importante. Contudo, ela não impõe limites a uma adaptação teórica à luz das discussões de Hamilton, ou das análises críticas, para quem o viés também poderia ocorrer em razão das preferências políticas dos proprietários dos veículos de imprensa.

O índice de viés de cobertura inspirado no trabalho de Bernhardt, Krasa e Polborn é construído a partir da soma de notícias positivas e negativas publicadas, respectivamente, sobre um candidato e seu principal concorrente. Isso porque eles assumem que os cidadãos preferem, ceteris paribus, "ouvir notícias que são positivas para o candidato ideologicamente mais próximo e negativas sobre o candidato oponente". (BERNHARDT, KRASA e POLBORN, 2006, p. 5) 
Um índice dessa natureza é mais adequado do que uma medida que considera, por exemplo, apenas o saldo das valências das matérias dos candidatos em um determinado período de tempo. Afinal, por mais que um candidato passe por um período de cobertura extremamente negativa, o seu impacto junto ao eleitorado será atenuado caso o seu principal concorrente também tenha sido duramente criticado nesse mesmo período (ZALLER, 1996). O contrário também é verdadeiro: coberturas positivas de candidatos concorrentes anulam os efeitos positivos para suas candidaturas. $\mathrm{O}$ ideal, portanto, é agregar as duas medidas.

Assim, para as eleições de 2002, 2006 e 2010, o número de matérias negativas dos candidatos do PT - Lula e Dilma Rousseff - foi somada ao número de matérias positivas publicadas sobre os candidatos do PSDB - José Serra e Geraldo Alckmin - e dividido pelo número total de matérias publicadas sobre ambos os concorrentes, inclusive as neutras e equilibradas. ${ }^{18}$ Isso permitiu a criação de um índice de viés da cobertura anti-PT ou pró-PSDB (IV anti-PT), escrito na seguinte notação matemática:

$$
I V_{\text {anti-PT }}=\left(Y_{\bar{P} T}+Y_{P S D B}^{+}\right) / N \times 100
$$

Onde $Y_{\bar{P} T}$ representa os valores da cobertura negativa dos candidatos petistas, $Y_{P S D B}^{+}$representa os valores da cobertura positiva sobre os candidatos tucanos, e $N$ é o número total de matérias publicadas sobre ambos, incluindo as neutras e equilibradas. Para facilitar a leitura dos dados, os valores obtidos variam de 0 a 100. Quanto mais próximo de 100 , maior o viés a anti-PT e, quanto mais próximo de 0 , menor o viés. ${ }^{19}$

$\mathrm{Na}$ construção do índice, utilizei um período temporal diferente do adotado na discussão sobre a distribuição de espaço nos jornais. Não há razões teóricas para supor que ele varie em função

18 O índice foi construído levando-se em conta apenas os dois principais concorrentes de cada eleição. Em 2002, 2006 e 2010 isso representou, respectivamente, 64\%, 92\% e 94\% (média = 83\%) da cobertura total dos veículos incluídos na análise.

19 Por razões de simplicidade, a partir de agora irei me referir ao índice de viés da cobertura apenas como índice de viés anti-PT. 
da posição dos candidatos na preferência dos eleitores, já que a posição das elites midiáticas estaria dada de antemão, levando a uma cobertura desequilibrada desde o início da disputa. Assim, para poder comparar a evolução das séries históricas nas três eleições, trabalharei com um intervalo de tempo semanal, que vai da $8^{\mathrm{a}}$ à $40^{\mathrm{a}}$ semana dos respectivos anos, que abarca o período de pré-campanha e $1^{\circ}$ turno das eleições.

Algumas outras informações técnicas devem ser mencionadas. Na eleição de 2006, agreguei o total de matérias publicadas sobre Lula Candidato e Lula Presidente em apenas uma categoria. Em 2010, incluí a cobertura sobre Lula Presidente como de um candidato petista na cobertura de Dilma. Além disso, foi necessário imputar dados de algumas semanas para Globo e Estadão em cada um dos anos. Para isso, utilizei o programa Amelia II (HONAKER e KING, 2010; KING et al, 2001). ${ }^{20}$

Os índices de viés anti-PT serão utilizados para analisar se três dos principais jornais brasileiros tiveram ou não um comportamento "padrão", que indicaria uma atitude de classe, nas eleições presidenciais brasileiras de 2002, 2006 e 2010. A hipótese nula a ser testada é:

: Não existe diferença estatisticamente significativa na cobertura realizada pelos jornais Folha, Estadão e Globo, em termos de viés anti-PT.

Esse comportamento homogêneo seria motivado por razões ideológicas, sem levar em conta as preferências e características dos respectivos leitores dos veículos, nem questões ligadas à concorrência de mercado e posicionamento de marca, conforme as indicações das teorias mais críticas sobre a produção de notícias.

20 As semanas para o Globo foram: 11 e 19 para 2006 e 10, 23, 24 e 38 para 2010. Para o Estadão foram: 14 em 2002, 40 em 2006 e 21, 33 e 34 em 2010. 


\section{Análise do viés anti-PT nas eleições de 2002, 2006 e 2010}

O Gráfico 2 a seguir apresenta os percentuais médios de votos e de espaço ocupado dos principais candidatos, na cobertura conjunta dos três jornais analisados, em cada uma das eleições. Fica claro que os concorrentes mais bem colocados, ou mais importantes politicamente, sempre obtiveram maior visibilidade.

Gráfico 2: Comparação entre o espaço nos jornais e os votos dos candidatos (distribuição e valores \% médios)

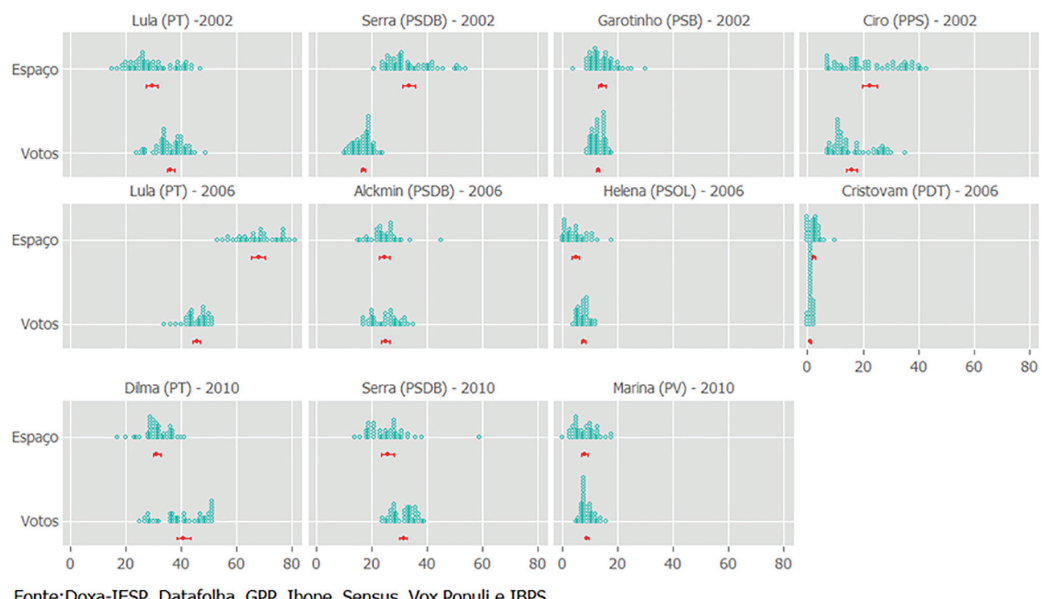

Fonte:Doxa-IESP, Datafolha, GPP, Ibope, Sensus, Vox Populi e IBPS

Uma relação dessa natureza estaria em desacordo com a premissa de que o importante, para os veículos de imprensa, é o posicionamento ideológico dos concorrentes e seus partidos, e não a sua posição na corrida eleitoral. Mas é preciso realizar testes mais robustos que corroborem as conclusões geradas pela análise visual.

De acordo com a hipótese 1 , as intenções de voto não deveriam impactar no espaço obtido pelos candidatos na cobertura dos jornais impressos. Ou seja, não deveria haver uma relação entre variação das intenções de voto dos concorrentes e o espaço obtido por eles nos veículos. 
Como os dados são de série temporal, uma forma de analisar a existência dessa relação é avaliar se a variação das intenções de voto dos candidatos seria capaz de prever a variação do espaço por eles nos jornais. Isso pode ser feito a partir de testes de causalidade de Granger, que "verifica se valores anteriores de uma variável aumentam a capacidade de previsão (...) de uma outra variável" (RENNÓ e SPANAKOS, 2006, p. 6). Em linguagem mais técnica, Bueno (2008, p. 189) explica: "pergunta-se se uma variável é capaz de prever outra e em que condições. Em outras palavras, a questão fundamental é saber se o escalar ajuda a prever o escalar. Se isso não ocorre, então diz-se que não-Granger-causa ". ${ }^{21}$

A Tabela 1 apresenta os resultados dos testes de causalidade de Granger para a evolução dos percentuais de votos e de espaço ocupado dos principais candidatos, na cobertura conjunta dos três jornais analisados. Caso estes sigam critérios ideológicos no espaço concedido em sua cobertura, a variação dos votos dos concorrentes não poderia ajudar a prever a variação do espaço obtido.

Tabela 1: Resultado dos testes de causalidade de Granger bivariados

\begin{tabular}{lcccc}
\hline Hipótese Nula & Obs. & Defasagens & Teste F & Prob. \\
\hline Eleição 2002 & & & & \\
\hline CIRO não-Granger-causa COBERTURA & 55 & 1 & 0.41507 & 0.5222 \\
\hline CIRO não-Granger-causa COBERTURA & 54 & 2 & 3.34047 & 0.0437 \\
\hline CIRO não-Granger-causa COBERTURA & 53 & 3 & 2.42370 & 0.0778 \\
\hline GAROTINHO não-Granger-causa COBERTURA & 55 & 1 & 1.16506 & 0.2853 \\
\hline GAROTINHO não-Granger-causa COBERTURA & 54 & 2 & 3.23436 & 0.0478 \\
\hline GAROTINHO não-Granger-causa COBERTURA & 53 & 3 & 2.71476 & 0.0553 \\
\hline LULA não-Granger-causa COBERTURA & 55 & 1 & 0.78027 & 0.3811 \\
\hline LULA não-Granger-causa COBERTURA & 54 & 2 & 2.97619 & 0.0603 \\
\hline
\end{tabular}

21 Seguindo as recomendações de Bueno (2008) e Brandt e Williams (2007), todas as séries incluídas na análise são estacionárias - testes ADF para raiz unitária. 


\begin{tabular}{|c|c|c|c|c|}
\hline LULA não-Granger-causa COBERTURA & 53 & 3 & 2.79473 & 0.0507 \\
\hline SERRA não-Granger-causa COBERTURA & 55 & 1 & 4.36209 & 0.0417 \\
\hline SERRA não-Granger-causa COBERTURA & 54 & 2 & 2.00188 & 0.1460 \\
\hline SERRA não-Granger-causa COBERTURA & 53 & 3 & 1.24841 & 0.3032 \\
\hline \multicolumn{5}{|l|}{ Eleição 2006} \\
\hline ALCKMIN não-Granger-causa COBERTURA & 36 & 1 & 0.08716 & 0.0048 \\
\hline ALCKMIN não-Granger-causa COBERTURA & 35 & 2 & 1.87572 & 0.1708 \\
\hline C. BUARQUE não-Granger-causa COBERTURA & 36 & 1 & 10.0228 & 0.4068 \\
\hline C. BUARQUE não-Granger-causa COBERTURA & 35 & 2 & 5.19659 & 0.0115 \\
\hline H. HELENA não-Granger-causa COBERTURA & 36 & 1 & 1.78892 & 0.1902 \\
\hline H. HELENA não-Granger-causa COBERTURA & 35 & 2 & 0.92688 & 0.0033 \\
\hline LULA não-Granger-causa COBERTURA & 36 & 1 & 10.3032 & 0.0030 \\
\hline LULA não-Granger-causa COBERTURA & 35 & 2 & 6.40388 & 0.7697 \\
\hline \multicolumn{5}{|l|}{ Eleição 2010} \\
\hline DILMA não-Granger-causa COBERTURA & 42 & 1 & 0.57930 & 0.4512 \\
\hline DILMA não-Granger-causa COBERTURA & 41 & 2 & 0.51278 & 0.6031 \\
\hline MARINA não-Granger-causa COBERTURA & 42 & 1 & 1.52431 & 0.2244 \\
\hline MARINA não-Granger-causa COBERTURA & 41 & 2 & 3.45355 & 0.0425 \\
\hline SERRA não-Granger-causa COBERTURA & 42 & 1 & 0.01656 & 0.8983 \\
\hline SERRA não-Granger-causa COBERTURA & 41 & 2 & 0.82667 & 0.4456 \\
\hline
\end{tabular}

Fonte: Doxa-IESP

Obs.: 0 número de defasagens foi definido a partir dos resultados de testes AIC, SC e HQ.

Mas os resultados da Tabela 1 mostram algo diferente. Nas três eleições as intenções de voto dos candidatos contribuíram para prever a variação do percentual de espaço ocupado por eles nas páginas dos jornais. As duas únicas exceções foram para Dilma e Serra em 2010. Naturalmente, por serem os dois principais concorrentes nessa eleição e pela importância política de seus respectivos partidos em todas as disputas presidenciais no Brasil desde 1994, o espaço ocupado pela petista e pelo tucano nos jornais já era naturalmente alto. 
Os dados analisados neste item não corroboram a hipótese do comportamento de classe da imprensa. Eles apontam para outra direção. Ao cobrirem as eleições presidenciais os jornais brasileiros adotaram como critério de visibilidade a posição ocupada pelos candidatos na disputa em termos de intenção de votos e a sua importância política. Ou seja, ao menos em termos de visibilidade, o critério de noticiabilidade dos jornais está mais próximo de um jornalismo comercial do que de um posicionamento motivado por razões ideológicas dos proprietários dos veículos.

\section{Diferentes jornais, visibilidades diferentes?}

$\mathrm{O}$ item anterior analisou os critérios de visibilidade conjunta adotado por três grandes jornais brasileiros nas eleições presidenciais de 2002, 2006 e 2010. Agora, o objetivo é testar comparativamente as conclusões expostas. Por razões comerciais e de preferência de seus leitores, os veículos tenderiam a adotar diferentes estratégias de visibilidade dos candidatos. Por exemplo, jornais de direita dariam mais espaços a candidatos de direita, enquanto jornais sem preferência definida apresentariam uma cobertura mais equilibrada.

Mas como sugere a hipótese 2, motivações ideológicas interferem diretamente nos critérios de noticiabilidade dos jornais, o que levaria a um comportamento homogêneo da imprensa. Uma maneira de confirmar ou refutar essa hipótese é comparar as médias do percentual do espaço ocupado por candidato em cada um dos jornais.

Resultados de testes ANOVA mostram que, em 2002, houve diferença significativa na média do espaço ocupado pelos candidatos Lula, Serra e Garotinho nos jornais A maior diferença foi para Garotinho . Testes HSD de Tukey (não apresentados aqui) indicam que essa diferença se encontra entre o jornal carioca e os jornais paulistas, influenciada pela interferência de questões regionais e mercadológicas no conteúdo dos veículos. ${ }^{22}$ Como ex-governador

22 Os resultados dos testes HSD de tukey podem ser obtidos mediante solicitação ao autor. 
do Rio de Janeiro, o candidato do PSB tinha no seu estado uma base eleitoral significativa, além do histórico político. Consequentemente, atraía o interesse dos leitores e ganhava mais espaço no Globo, apesar de baixas intenções de voto no cômputo geral.

Em 2006, somente Heloísa Helena ocupou um espaço igual na cobertura dos jornais $(F[2,110]=0.35, p=.71)$, o oposto do que aconteceu com os outros três concorrentes $(F[2,110]=5.46, \mathrm{p}=.01$, valores médios). Dois fatores podem ter motivado esse cenário: ser uma candidata de menor expressão, que não conseguiu ganhar fôlego em nenhum momento, e não ter uma base eleitoral consolidada em grandes centros como São Paulo e Rio de Janeiro. Alguns analistas poderiam levantar o argumento de que a candidata do PSOL tenha sofrido de uma espécie de "preconceito ideológico" dos "barões da imprensa", já que era uma concorrente de um partido de esquerda. Para isso ser verdade, as suas intenções de voto não poderiam ter influenciado o percentual do espaço obtido na cobertura dos jornais. Mas isso não aconteceu, como mostram os dados da Tabela 1.

Em relação aos demais candidatos, é importante dizer que os jornais não agiram em uníssono em relação ao espaço concedido. Novamente, testes de HSD de Tukey (não apresentados aqui) indicaram que Lula realmente obteve sua maior parcela de visibilidade no Estadão. Alckmin apareceu mais na Folha do que nos demais veículos. E Cristovam ganhou mais espaço em O Globo.

Em 2010, não houve diferença estatisticamente significativa no espaço ocupado pelos candidatos nos três jornais $(F[2,131]=2.22, p=.11$,valores médios $)$. Apenas neste pleito seria possível dizer que os jornais se comportaram como se tivessem um "mesmo editor". Em todo caso, os resultados dos testes indicam que são mais fortes as evidências para rejeitar essa hipótese do que para aceitá-la.

Mas esses mesmos testes explicitam os limites da análise do viés midiático levando-se em conta apenas o espaço dado pelos jornais. Por um lado, eles foram importantes para mostrar como fatores comerciais e regionais interferiram na visibilidade obtida pelos candidatos. Por outro, eles não mostram, por exemplo, que 
a visibilidade obtida por Lula em 2006 no Estadão foi qualitativamente negativa, não trazendo vantagens ao petista. Nesse sentido, o equilíbrio na visibilidade não se traduziu, necessariamente, em um equilíbrio na cobertura.

\section{São as valências, "estúpido"?}

Neste item utilizo o índice de viés anti-PT para avaliar o viés de cobertura política da imprensa. Assumo, teoricamente, a posição de que Folha, Estadão e Globo são anti-PT, posição esta cujas "sementes" encontram-se "ainda na primavera da nossa abertura política, em 1989” (KUCINSKI, 2007, p. 134). Tal afirmação permite sustentar que os jornais se associaram para prejudicar, enfraquecer ou minar as candidaturas petistas nas eleições presidenciais e que a cobertura dos três veículos não apresentou diferenças substantivas na quantidade de críticas a Lula e Dilma e "elogios" aos seus adversários tucanos.

O Gráfico 3 traz as séries históricas do viés anti-PT nas três eleições analisadas na cobertura conjunta de Folha, Globo e Estadão. Optei por separar o conteúdo da cobertura das partes informativas e opinativas dos veículos. ${ }^{23} \mathrm{O}$ objetivo foi comparar as partes que, pelo princípio da objetividade jornalística (GANS, 1980; SCHUDSON, 1981; HAMILTON, 2004), tenderiam a ser menos enviesadas, com aquelas onde os posicionamentos políticos estariam mais expostos, permitindo uma melhor compreensão das inclinações das coberturas dos jornais analisados. ${ }^{24} \mathrm{~A}$ eleição de 2006 foi a que teve maior viés de cobertura, e a de 2002 o menor. Como era de se esperar, o conteúdo opinativo apresentou valores mais altos do que o informativo. No que se segue, darei ênfase à distinção feita entre esses dois tipos de cobertura, pois elas ilustram de maneira mais clara o comportamento político dos jornais.

23 Para a divisão entre conteúdo informativo e opinativo, segui procedimento semelhante ao adotado por Aldé, Mendes e Figueiredo (2007). Editoriais, colunas, artigos assinados e charges foram classificados como "opinião", enquanto reportagens, infográficos, fotos e chamadas foram classificados como "informação".

24 A planilha de monitoramento da cobertura da mídia impressa do Doxa-IESP permite outros recortes, como por exemplo o tipo de enquadramento da cobertura. 
Gráfico 3: Evolução do índice de viés anti-PT nas eleições presidenciais brasileiras de 2002, 2006 e 2010, cobertura conjunta de Folha, Estadão e Globo.
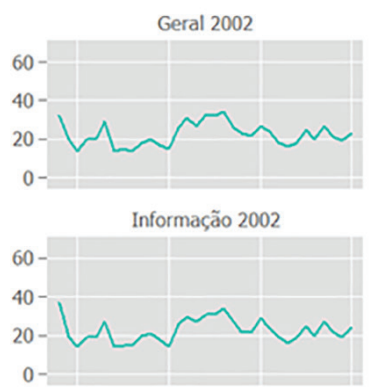

Opinião 2002

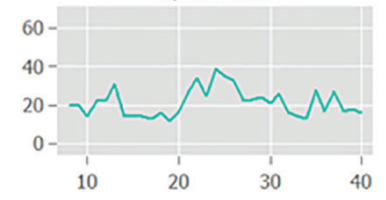

Fonte: Doxa-IESP

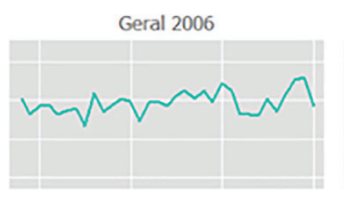

Informação 2006

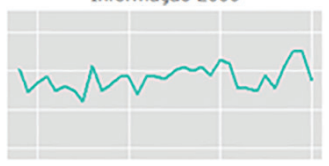

Opinião 2006

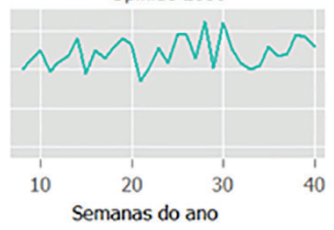

Geral 2010

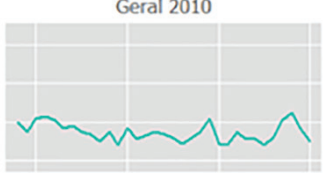

Informação 2010

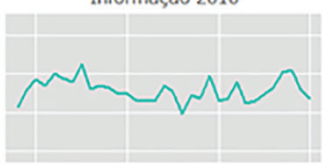

Opinião 2010

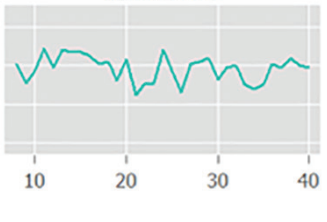

\section{O Estadão como parâmetro do viés da cobertura anti-PT}

Uma das grandes dificuldades dos estudos sobre viés midiático é a definição daquilo que se poderia chamar de "centro do espectro político" para, a partir daí, definir se um jornal é de esquerda ou de direita (ENTMAN, 2007; GROELING, 2008, 2013; GASPER, 2011). Groseclose e Milyo (2005), por exemplo, argumentaram que essa é uma decisão relativamente “arbitrária”. Não pretendo apresentar uma solução para este problema, aqui, pois, nem os dados nem o índice de viés anti-PT me permitem fazê-lo. O máximo que se pode dizer com eles é que um jornal teve, ou não, uma cobertura mais ou menos desfavorável aos candidatos petistas.

Em 2002 e 2006, o Estadão endossou publicamente os candidatos tucanos (ALDÉ, MENDES e FIGUEIREDO, 2007; ALDÉ, 2003). Esse fato dá a ele uma importante função analítica, pois quando apenas um jornal se posiciona abertamente a favor de um partido ou candidato, pode ser utilizado como ponto de referência. Por 
conta disso, o Estadão será um parâmetro de comparação com os demais veículos. Quanto maior (menor) a diferença de uma cobertura em relação ao periódico paulista, maior (menor) o viés anti-PT apresentado. Quanto maior (menor) essa diferença, mais heterogêneo (homogêneo) é o comportamento político dos jornais.

Para a comparação do viés dos jornais irei, novamente, fazer uso dos testes ANOVA e HSD de Tukey, que permitirão definir se um ou mais veículos tiveram, na média, uma cobertura diferente da executada pelo Estadão. Os resultados podem ser vistos no Gráfico 4.

Gráfico 4: Distribuição e valores médios do índice de viés de cobertura anti-PT por jornal nas eleições presidenciais de 2002, 2006 e 2010

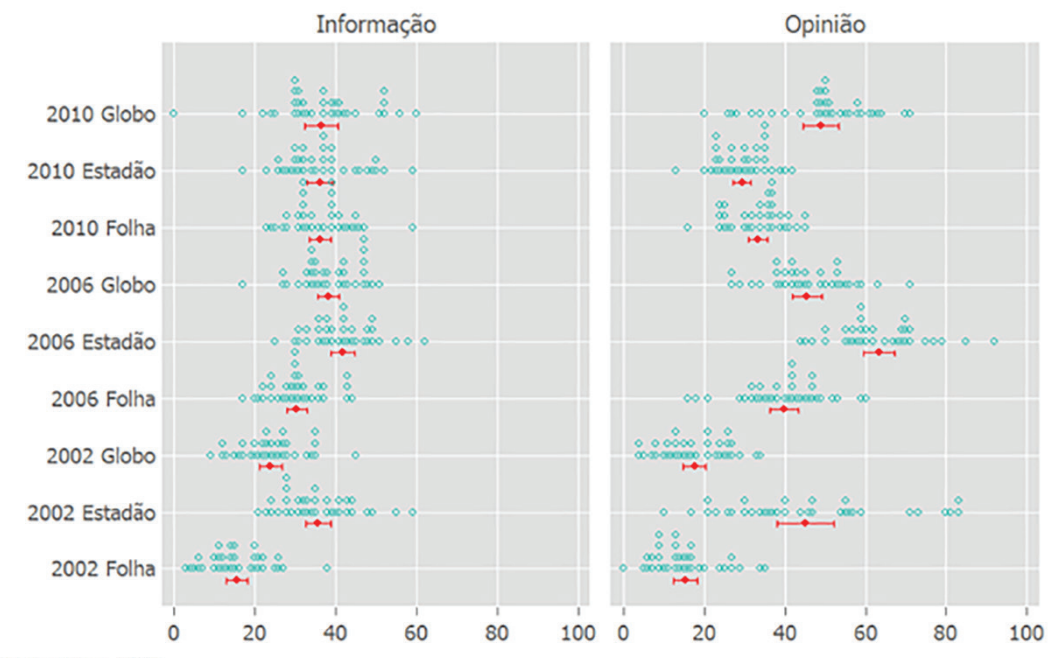

Fonte: Doxa-IESP

A interpretação dos resultados do gráfico 4 auxilia no entendimento do comportamento político da imprensa entre 2002 e 2010. No geral, esperava-se que o Estadão se diferenciasse dos demais veículos, sendo mais crítico ao PT. Embora esse tenha sido claramente o padrão em 2002 e 2006, especialmente no conteúdo opinativo, o mesmo não ocorreu em 2010, quando a cobertura de 
Folha e Estadão não se diferenciou em seus valores médios e o Globo apresentou um maior viés anti-PT no seu conteúdo opinativo.

Contudo, a informação mais importante apresentada pelos dados é a rejeição da hipótese nula sobre a homogeneidade da cobertura jornalística. Isso ocorreu em apenas um cenário: no conteúdo informativo em 2010. Na média Folha, Estadão e Globo realizaram coberturas diferentes.

No conteúdo informativo, a distância entre os veículos é menor e o viés anti-PT é mais ameno na média geral das três eleições, como se pode ver tanto no Gráfico 4 quanto na Tabela $2 .{ }^{25}$ Entendo que esse comportamento mais homogêneo aconteceu por causa de valores jornalísticos como objetividade, neutralidade e pluralidade, independente das várias críticas que podem ser feitas a eles (TUCHMAN, 1972; GANS, 1980; SCHUDSON, 1981; KUKLINSKY e SILGEMAN, 1992; ALBUQUERQUE, 2000; MATOS, 2008). Assim, a ideia do "editor único" ocorreria não pelo desejo de uma cobertura mais crítica a um partido ou candidato, mas por um desejo das elites midiáticas de realizarem uma cobertura mais equilibrada. Como argumentou Hamilton (2004), esses preceitos seriam motivados mais por objetivos comerciais dos veículos do que por preferências ideológicas e valorativas.

Tabela 2: Estatísticas descritivas do viés anti-PT por tipo de cobertura (2002-2010)

\begin{tabular}{cccccc}
\hline & Média & Desvio-Padrão & Min & Max & Obs. \\
\hline Informação & 32 & 10 & 0 & 62 & 444 \\
\hline Opinião & 39 & 18 & 0 & 92 & 356 \\
\hline
\end{tabular}

Fonte: Doxa-IESP

Essa interpretação sobre a objetividade jornalística não se aplica, da mesma forma, ao conteúdo opinativo. Em primeiro lugar, porque este seria o espaço onde preferências ideológicas poderiam se manifestar de maneira mais livre, sem a coerção de objetivos

25 Testes ANOVA ( $F[1,800]=53.65, p=.00)$ confirmaram que essa diferença é estatisticamente significativa. 
comerciais. Em segundo lugar, porque, como fica óbvio com os dados apresentados, o viés da cobertura anti-PT foi maior - algumas vezes, bem maior.

Ainda, assim, alguns pontos ficam claros. Em duas eleições, 2002 e 2006, o Estadão colocou-se em uma posição contrária ao PT, em comparação à Folha e ao Globo. Embora 2006 tenha sido o ano em que o periódico paulista fez a sua cobertura mais crítica, tendo alcançado o maior valor médio entre todas as medições do índice de viés anti-PT, 62 pontos, foi em 2002 que o Estadão expressou, de maneira mais forte, a sua oposição ao partido e seu candidato. Nesta eleição, a diferença média do viés anti-PT entre o Estadão e os outros dois jornais foi de 28 pontos, enquanto em 2006 a diferença foi de 19 pontos.

Por um lado, o fato de a eleição que reelegeu o ex-presidente Lula ter sido a que apresentou a cobertura mais crítica ao PT mostra, a meu ver, o quanto o escândalo político do Mensalão, que afetou o seu primeiro mandato, contaminou o conteúdo dos três jornais analisados, levando a uma cobertura mais negativa em 2006 do que em 2002. Por outro, embora seja possível dizer que Estadão, Folha e $O$ Globo seguiram a mesma tendência ao tratar de temas políticoeleitorais em seus espaços opinativos, não é possível dizer que eles apresentaram comportamentos literalmente homogêneos, ou seja, tiveram o mesmo nível de criticismo.

Por fim, vale ressaltar a "virada crítica" de O Globo entre 2006 e 2010, quando o jornal carioca tomou a frente da divulgação do conteúdo negativo ao PT. Talvez isso se explique pelo fato de que, em 2010, os questionamentos a Serra tenham sido maiores. O tucano entrou na disputa sendo mais contestado, mesmo em São Paulo. Em 2008, por exemplo, quando venceu a eleição para prefeito na capital paulista, ele prometeu que permaneceria no cargo e não disputaria a eleição presidencial, fato que o desgastou junto aos eleitores. Esse era um problema menor para os cariocas, o que poderia explicar em parte o tom mais crítico de O Globo em 2010. 


\section{Considerações finais}

Houve viés na cobertura política de Folha, Estadão e O Globo nas eleições de 2002, 2006 e 2010? Sim, mas essa interpretação precisa ser relativizada. Seria partir de uma premissa extremamente rigorosa - e até mesmo irreal, dado um período de 32 semanas de análise e o fato de pelo menos um dos jornais ter se declarado a favor dos candidatos tucanos - exigir que os valores do índice de viés anti-PT, que varia de 0 a 100, estivessem sempre muito próximos de zero, seja porque os veículos foram críticos em relação a petistas e tucanos, seja porque foram benevolentes.

Uma leitura mais realista seria a seguinte. É possível dizer que Folha, Estadão e Globo tiveram, sim, "um tom mais negativo sobre um candidato do que os demais". Ou seja, houve viés de cobertura. Mas isso não deve ser entendido como sinônimo de uma cobertura sistematicamente enviesada, pois existiram momentos mais críticos do que outros, e jornais mais críticos do que outros. O momento de maior intensidade do viés anti-PT aconteceu em 2006, no conteúdo opinativo dos jornais, principalmente no Estadão. Embora a presença de posicionamentos políticos seja, em princípio, aceitável nesses espaços, autores como Aldé, Mendes e Figueiredo (2007, p. 163) questionaram a conduta dos veículos nessa eleição, que consideraram "negativa demais para ser apartidária".

De todo modo, os dados sugerem que os três jornais fizeram coberturas diferentes, seja no conteúdo informativo, seja no opinativo. A hipótese de homogeneidade da cobertura foi rejeitada pelos testes empíricos, tanto com os indicadores de visibilidade dos candidatos quanto com o índice de viés anti-PT. Além disso, o viés anti-PT variou, sim, entre as eleições e entre os veículos, o que torna difícil aceitar a ideia da existência de uma "grande imprensa" voltada, insistentemente, contra os candidatos petistas. É verdade que, em certos momentos, as coberturas dos três jornais foram semelhantes. Mas não apenas de maneira mais negativa, como se pode ver na cobertura do conteúdo informativo.

Tudo indica que, da mesma forma que existem razões para as elites midiáticas contaminarem as notícias com ideologia, existem 
também constrangimentos - econômicos, contextuais etc. - que diminuem seus incentivos nessa direção. Para alguns veículos pode ser uma boa estratégia enviesar a cobertura, especialmente quando isso não representa uma perda de leitores e, consequentemente, de anunciantes e de receita (XIANG e SARVARY, 2007). Este poderia ser, por exemplo, o caso do Estadão.

Mas se a maioria dos leitores dos jornais não tem posicionamentos políticos extremos e prefere coberturas mais neutras, editores e jornalistas, interessados em agradar o seu público-alvo e em alavancar as suas carreiras, provavelmente farão matérias mais neutras (BOVITZ et al., 2002). Esse poderia ser o caso da Folha, para quem enviesar a cobertura poderia ser o mesmo que sacrificar parte dos lucros por ideologia. Segundo Aldé (2003, p. 112), o periódico paulista sempre buscou um tom mais "crítico" e "combativo". Se isso é verdade, o jornal provavelmente atrai um leitor com perfil ideológico diferente do Estadão. Parte da explicação para a diferença da cobertura entre os dois veículos estaria justamente nessa questão comercial, de posicionamento de marca em um mercado restrito.

Por fim, é importante ressaltar algumas limitações dos dados e análises deste artigo. Recentemente houve um debate bastante acalorado sobre o uso das valências como um indicador do viés da cobertura (MIGUEL, 2015, 2016; FERES JÚNIOR, 2016ab). Não pretendo retomá-la aqui. Embora concorde que o indicador possui problemas de validade, a solução proposta por Miguel - deixar pesquisas como as do Doxa-IESP nas gavetas da história - é errada. Concordo, portanto, com a resposta de Feres Júnior e acredito que trabalhar com os tradicionais conceitos de negativo, neutro e positivo ainda seja um critério plenamente aceitável do ponto de vista científico.

Não é possível extrapolar as conclusões apresentadas para eleições presidenciais anteriores a 2002 e posteriores a 2014, já que não disponho de dados, colhidos e analisados a partir da mesma metodologia, sobre pleitos anteriores. O fato de dados de 2014 estarem disponíveis pelo Manchetômetro não resolve o problema. 
O recorte - manchetes de jornais - limita muito a possibilidade de comparação com os dados do Doxa-IESP.

Embora sejam indiscutíveis a importância política e econômica e o poder de influência de Folha, Estadão e Globo, não existem garantias de que o comportamento político desses jornais seja reproduzido em outros periódicos do país. Na verdade, não ficaria surpreso em encontrar situações de vieses de cobertura ainda mais fortes contra partidos ou candidatos, principalmente em cidades, estados ou regiões onde os veículos são mais dependentes, financeiramente, do apoio governamental, ou de propriedade de políticos. (ABRAMO, 2007; DUNAWAY, 2008; BOAS e HIDALGO, 2011)

Acredito que oíndice de viés anti-PT seja, teórica e empiricamente, mais adequado para se analisar o viés da cobertura política da imprensa, tendo em vista os seus efeitos junto aos eleitores. Mas uma análise que buscasse entender como o viés de cada eleição se constituiu precisaria de uma leitura mais profunda do material jornalístico. Ou seja, deveria ser completada com análises qualitativas.

Por exemplo, em 2002, segundo apontou Aldé (2003, p. 111), o Estadão "foi o jornal mais parcial analisado". Isso justifica o valor médio mais alto do índice de viés anti-PT alcançado pelo periódico. Contudo, para Folha e Globo, os baixos valores obtidos no mesmo índice teriam razões distintas. Enquanto para o jornal carioca deveu-se à "benevolência adotada no trato de Lula" e à generosidade "com a campanha do candidato oficial", ou seja, um baixo viés por uma cobertura mais positiva, no jornal paulista isso ocorreu por conta do posicionamento mais crítico em relação a todos os candidatos (ALDÉ, 2003, p. 112), ou seja, um baixo viés por uma cobertura mais negativa.

As discussões feitas referem-se apenas à cobertura política em contextos eleitorais. Elas não me permitem dizer nada sobre o posicionamento ideológico dos jornais em relação a questões políticas de outra natureza, como, por exemplo, questões de gênero, raça, sexualidade e legalização das drogas. Além disso, acredito que a cobertura política de eventos recentes, principalmente sobre 
a operação Lava Jato e o impeachment da ex-presidente Dilma, fugiriam completamente do padrão médio descrito neste artigo, para um padrão muito mais negativo do que o observado.

De maneira "restrita", seria possível falar em esquerda e direita na imprensa brasileira? Não me arriscaria a ir tão longe, ao menos com os dados e métricas utilizadas neste artigo, e os resultados apresentados. Os indicadores de visibilidade e viés de cobertura não medem a ideologia dos veículos, ainda que muitas das críticas sobre o comportamento dos jornais durante as eleições apresentadas na discussão teórica apontem para questões dessa natureza (GOMES, 2016).

Em suma, o que se pode dizer é que os três jornais analisados seguiram critérios de noticiabilidade aceitáveis, ao menos no conteúdo informativo; apresentaram coberturas mais diferentes do que semelhantes; e que uns foram mais críticos do que outros. A meu ver, esses posicionamentos não se justificam apenas do ponto de vista ideológico, mas também de mercado. Nesse sentido, a cobertura da imprensa pode apresentar um viés, não necessariamente, e apenas, por razões ideológicas.

\section{Referências bibliográficas}

ABRAMO, Claudio W. A portrait of disparities: an analysis of Brazilian newspapers. Brazilian Journalism Research, v. 3, n. 1, p. 93-107, 2007.

ALBUQUERQUE, Afonso de. Um outro quarto poder: jornalismo e compromisso político no Brasil. Contracampo, v. 4, p. 23-57, 2000.

ALDÉ, Alessandra. As eleições presidenciais de 2002 nos jornais. Alceu, v. 3, n. 1, p. 93-116, 2003.

; MENDES, Gabriel e FIGUEIREDO, Marcus. Tomando partido: imprensa e eleições presidenciais em 2006. Política e Sociedade, v. 10, p. 153-172, 2007.

AMARAL, Roberto. As eleições de 2006 e a emergência das grandes massas no processo político. Comunicação e política, v. 24, n. 3, p. 7-17, 2006. 
ARMONY, Flávio S. O viés da imprensa paulistana nas eleições municipais de 2008: um novo método de mensuração. Comunicação e política, v. 27, n. 2, p. 11-30, 2009.

AZEVEDO, Fernando. A imprensa brasileira e o PT: um balanço das coberturas das eleições presidenciais (1989-2006). ECO-Pós, v. 12, n. 3, p. 48-65, 2009.

. Corrupção, mídia e escândalos midiáticos no Brasil. Em Debate, v. 2, n. 3, p. 14-19, 2010.

. Eleições presidenciais, clivagem de classe e declínio da grande imprensa. Revista USP, n. 90, p. 84-101, 2011.

BOAS, Taylor e HIDALGO, Daniel. Controlling the airwaves: incumbency advantage and community radio in Brazil. American Journal of Political Science, v. 55, n. 4, p. 1-17, 2011.

BARON, David P. Persistent media bias. Journal of Public Economics, v. 90, p. 1-36, 2006.

BERNHARDT, Dan, KRASA, Stephen e POLBORN, Mattias. Political polarization and the electoral effects of media bias. CESifo Working Paper Series, n. 1.798, 2006.

Political Polarization and the Electoral Effects of Media Bias. Journal of Public Economics, v. 92, p. 1.092-1.104, 2008.

BOVITZ, Gregory L.; DRUCKMAN, James e LUPIA, Arthur. When Can News Organization Lead Public Opinion? Ideology versus market forces in decisions to make news. Public Choice, v. 113, p. 127-155, 2002.

BRANDT, Patrick T. e WILLIAMS, John T. Multiple TIME SERIES MODELS. Thousand Oaks, Sage Publications, 2007.

BUENO, Rodrigo. Econometria de SÉRIES TEMPORAIS. São Paulo, Cengage Learning, 2008.

CAMARGOS, Malco e OLIVEIRA, Luis Ademir de. análise da cobertura dos jornais O Tempo e Estado de Minas no período pré-eleitoral da eleição municipal para Prefeito em Belo Horizonte (mimeo), 2000. 
CERVI, Emerson. A cobertura da imprensa e as eleições presidenciais 2002. BOCC - Biblioteca On-line de Ciências da Comunicação, v.1, p.1-68, 2003.

COOK, Timothy E. Jornalismo político. Revista Brasileira de Ciência Política, n.6, p.203-47, 2011.

D’ALESSIO, Dave e ALLEN, Mike. Media Bias in Presidential Elections: a meta-analysis. Journal of Communication, v. 50, n. 4, p. 133-156, 2000.

DELLAVIGNA, Stefano e KAPLAN, Ethan. The fox news effect: media bias and voting. The Quarterly Journal of Economics, v. 122, n. 3, p. 1.187-1.234, 2007.

DOWNS, Anthony. Uma teoria econômica de democracia. São Paulo, EDUSP, 1957 (1999).

DRUCKMAN, James e PARKIN, Michael. The impact of media bias: how editorial slant affects voters. The Journal of Politics, v. 67, n. 4, p. 1.030-1.049, 2005.

DUNAWAY, Johanna. Markets, ownership, and the quality of campaign news coverage. The Journal of Politics, v.70, n. 4, p. 1.193-1.202, 2008.

ENTMAN, Robert. Framing bias: media in the distribution of Power. Journal of Communication, v. 57, p. 163-173, 2007.

FERES JÚNIOR, João. Análise de valências, debate acadêmico e contenda política. Revista Brasileira de Ciência Política, n. 20, p. 313-322, 2016a.

. Em defesa das valências: uma réplica. Revista Brasileira de Ciência Política, n. 19, p. 277-298, 2016 b.

; SASSARA, Luna de Oliveira. O cão que nem sempre late: o Grupo Globo e a cobertura das eleições presidenciais de 2014 e 1998. Revista Compolítica, v. 6, n. 1, p. 30-63, 2016.

GASPER, John T. Shifting Ideologies? Re-examining media bias. Quarterly Journal of Political Science, v. 6, n. 1, p. 85-102, 2011. GANS, Herbert J. Deciding what's news: a study of CBS evening news, NBC nightly news, newsweek, and time. New York, Vintage, 1980. 
GENTZKOW, Matthew e SHAPIRO, Jesse M. What drives media slant? Evidence from u.s. daily newspapers. Econometrica, v. 78, n. 1, p. 35-71, 2010.

GERBER, Alan; KARLAN, Dan; BERGAN, Daniel. Does the media matter? A field experiment measuring the effect of newspapers on voting behavior and political opinions. American Economic Journal: Applied Economics, v. 1, n. 2, p. 35-52, 2009.

GERRING, John. Ideology: a definitional analysis. Political Research Quarterly, v. 50, n. 4, p. 957-94, 1997.

GOMES, Wilson. Por que a mídia é tão parcial e adversária da minha posição? A hipótese

da "hostile media perception". Revista Compolítica, v. 6, n. 1, p. 7-29, 2016.

GRABE, Maria Elizabeth; KAMHAWI, Rasha e YEGIYAN, Narine. Informing citizens: how people with different levels of education process television, newspaper, and web news. Journal of Broadcasting \& Electronic Media, v. 53, n. 1, p. 90-111, 2009.

GROELING, Tim. Media bias by the numbers: challenges and opportunities in the empirical study of partisan news. Annual Review of Political Science, v. 16, p. 129-151, 2013.

. Who's the fairest of them all? An empirical test for partisan bias on ABC, CBS, NBC, and Fox News. Presidential Studies Quarterly, v. 38, n. 4, p. 631-657, 2008.

; KERNEL, Samuel. Is network news coverage of the president biased? The Journal of Politics, v. 60, n. 4, p. 1.0631.087, 1998.

GROSECLOSE Tim e MILYO, Jeffrey. A Measure of Media Bias. The Quarterly Journal of Economics, vol.120, n.4, p. 1191-1237, 2005.

HAMILTON, James T. All the news that's fit to sell: how market transforms information into news. Princeton, Princeton University Press, 2004.

News that sells: media competition and news content. Japanese Journal of Political Science, v. 8, n. 1, p. 7-42, 2007. 
HONAKER, James e KING, Gary. What to do about missing values in time series cross-section data. American Journal of Political Science, v. 54, n. 2, p. 561-581, 2010.

IYENGAR, Shanto e HAHN, Kuy. Red media, blue media: evidence of ideology selectivity in media use. Journal of Communication, v. 59, p. 19-39, 2009.

KAHN, Kin F. e KENNEY, Patrick. The slant of the news: how editorial endorsements influence campaign coverage and citizens' views of candidates. American Political Science Review, v. 96, n. 2, p. 381-394, 2002.

KING, Gary et al. Analyzing incomplete political science data: an alternative algorithm for multiple imputation. American Political Science Review, v. 95, n. 1, p. 49-69, 2001.

KUCINSKI, Bernardo. A Síndrome da antena parabólica: ética no jornalismo brasileiro. São Paulo: Editora Fundação Perseu Abramo, 1998.

. O antilulismo na campanha de 2006 e suas raízes. In: V. Lima (org.). A mídia nas eleições de 2006. São Paulo, Editora Fundação Perseu Abramo, p. 133-144, 2007.

KUKLINSKY, James e SIGELMAN, Lee. When objectivity is not objective: network television news coverage of U.S. Senators an $\mathrm{d}$ the 'Paradox of Objectivity'. The Journal of Politics, v. 54, n. 3, p. 810-833, 1992.

LATTMAN-WELTMAN, Fernando; RAMOS, Plínio de Abreu; CARNEIRO, Rogério. A imprensa faz e desfaz um presidente. Rio de Janeiro, Nova Fronteira, 1994.

- Mídia e transição democrática: a (des)institucionalização do pan-óptico no Brasil. In: A. Abreu, F. Lattman-Weltman e M. Kornis (orgs.), Mídia e Política no Brasil: Jornalismo e Ficção. Rio de Janeiro, Editora FGV, p. 129-183, 2003.

LIMA, Venício. Mídia: teoria e política. São Paulo: Editora Fundação Perseu Abramo, 2004.

MATOS, Carolina. Journalism and political democracy in Brazil. London: Lexington Books, 2008. 
MIGUEL, Lorena et al. Para além das valências: os termos depreciativos e os enquadramentos usados na cobertura da eleição presidencial de 2010. Anais do V Congresso da Compolítica [online]. 2013 [12-05-2014]. Disponível em http:// www.compolitica.org/home/wp-content/uploads/2013/05/ GT02-Midias-e-eleicoes-LorenaMiguel.pdf.

MIGUEL, Luis Felipe. Mídia e eleições: a Campanha de 1998 na Rede Globo. Dados, v. 42, n. 2, p. 253-276, 1999.

- A descoberta da política - a campanha de 2002 na Rede Globo. In: A. Rubim (org.), Eleições presidenciais de 2002 no Brasil: ensaios sobre mídia, cultura e política. São Paulo, Hacker Editores, p. 91-105, 2004.

. Quanto vale uma valência? Revista Brasileira de Ciência Política, n. 17, p. 165-178, 2015.

. Uma resposta. Revista Brasileira de Ciência Política, n. 19, p. 299-301, 2016.

MULLAINATHAN, Sendhil e SHLEIFER, Andrei. The market for news. The American Economic Review, v. 95, p. 131-153, 2005.

MUNDIM, Pedro Santos. Imprensa e voto nas eleições presidenciais brasileiras de 2002 e 2006. Revista de Sociologia \& Política, v.20, n.41, p. 123-47, 2012.

- Assistindo ao Jornal Nacional: determinantes da exposição aos principais telejornais brasileiros. Revista Debates, v. 9, n. 3, p. 37-62, 2015.

NASSIF, Luis. A longa noite de são Bartolomeu. In: V. Lima (org.). A mídia nas eleições de 2006. São Paulo, Editora Fundação Perseu Abramo, p. 149-158, 2007.

NUNOMURA, Eduardo. Diferenças e aproximações dos leitores da imprensa nacional e regional. Revista Debates, v. 9, n. 3, p. 97-118, 2015.

PORTO, Mauro. Democratization and election news coverage in Brazil. In: J. Strömbäck e L. Kaid (orgs.), The handbook of elections news coverage around the world. New York, Routledge, p. 252-272, 2008. 
. Media power and democratization in Brazil: TV Globo and the dilemmas of political accountability. New York, Routledge, 2012.

PRIOR, Markus. Media and political polarization. Annual Review of Political Science, v.16, p. 101-127, 2013.

PUGLISI, Riccardo. Being The New York Times: the political behaviour of a newspaper. The B.E. Journal of Economic Analysis \& Policy, v. 11, n. 1, p. 1-22, 2011.

RENNÓ, Lucio e SPANAKOS, Anthony P. Fundamentos da economia, mercado financeiro e intenção de voto: as eleições presidenciais brasileiras de 1994, 1998 e 2002. Dados, v. 49, n. 1, p. 11-40, 2006.

ROVAI, Renato. As muitas derrotas da mídia comercial tradicional. In: V. Lima (org.). A mídia nas eleições de 2006. São Paulo, Editora Fundação Perseu Abramo, p. 115-132, 2007.

SCHUDSON, Michael. Discovering the news: a social history of american newspapers. New York, Basic Books, 1981.

STEVENSON, Roger e GREENE, Mark T. A reconsideration of bias in the news. Journalism \& Mass Communication Quartely, v. 57, n .1, p. 115-121, 1980.

STONE, Daniel F. Ideological media bias. Journal of Economic Behavior \& Organization, v. 78, p. 256-271, 2011.

TUCHMAN, Gaye. Objectivity as strategic ritual: an examination of newsmen's notions of objectivity. American Journal of Sociology, v. 77, n. 4, p. 660-679, 1972.

XIANG, Yi e SARVARY, Miklos. News consumption and media bias. Marketing Science, v. 26, n. 5, p. 611-628, 2007.

ZALLER, John R. The myth of massive media impact revived: new support for a discredited idea. In: D. Mutz, P. M. Sniderman e R. A. Brody (orgs.), Political Persuasion and Attitude Change. Ann Arbor, The University of Michigan Press, p. 17-78, 1996.

WOOD, Thomas e OLIVER, Eric. Toward a more reliable implementation of ideology in measures of public opinion. Public Opinion Quarterly, v. 76, n. 4, p. 636-662, 2012. 


\section{Resumo}

O artigo analisa o viés da cobertura política da imprensa nas eleições presidenciais de 2002, 2006 e 2010, a partir da análise de conteúdo dos jornais Folha de S. Paulo, O Estado de S. Paulo e O Globo. Como primeira hipótese, avalia se o espaço concedido aos candidatos nos jornais estaria em desacordo com sua importância política ou sua posição na disputa eleitoral. Mas como esses critérios não garantem, necessariamente, um equilíbrio na cobertura, a segunda hipótese avalia se existe diferença significativa na cobertura realizada pelos jornais, a partir de um índice de viés de cobertura anti-PT. Os testes estatísticos utilizados foram causalidade de Granger, ANOVA e HSD de Tukey. Embora exista viés na cobertura da imprensa, principalmente no conteúdo opinativo, as análises rejeitaram a existência de um padrão claro e sistemático de preferência por um determinado partido ou candidato nas páginas dos jornais.

Palavras-chave: cobertura política da imprensa, viés midiático, eleições presidenciais brasileiras, jornais impressos.

\section{Abstract}

This article analyzes the political bias of the press coverage in the presidential elections of 2002, 2006 and 2010, based on the content analysis of the Folha de S. Paulo, O Estado de S. Paulo and O Globo newspapers. As a first hypothesis, it assesses whether the space granted to the candidates in the newspapers would be at odds with their political importance or their position in the electoral contest. However, since these criteria do not necessarily guarantee a balance in coverage, the second hypothesis evaluates whether there is a significant difference in coverage by the newspapers, based on an anti-PT coverage bias index. The statistical tests used were Granger causality test, ANOVA and Tukey's HSD. Although there are biases in the press coverage, mainly in the opinionated content, the analysis rejected the existence of a clear and systematic pattern of preference for a particular party or candidate on the newspapers' pages.

Keywords: press coverage, media bias, Brazilian presidential elections, printed newspapers

Recebido em: 17 de junho de 2017

Aprovado em: 30 de agosto de 2017 
